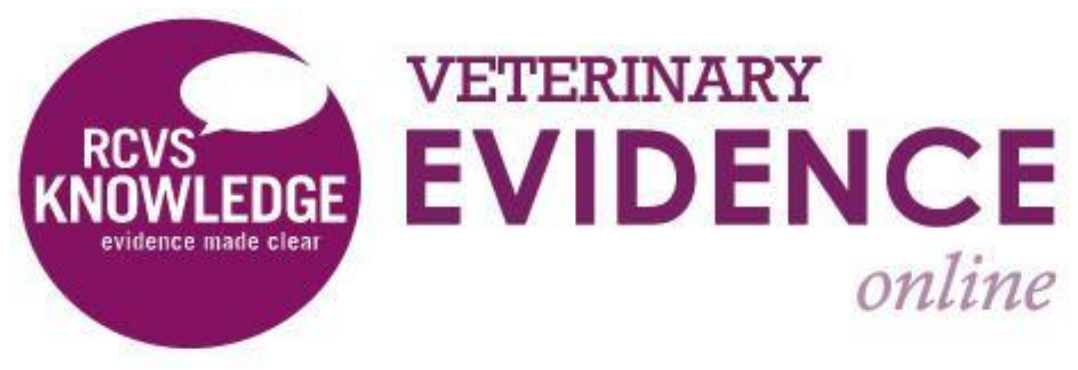

\title{
Does Heat Stress Affect Immune Function in Dairy Cows?
}

\author{
A Knowledge Summary by
}

Michael Steele BSc(Hons), BVSc, MRCVS ${ }^{1 *}$

\footnotetext{
1 Dairy Consultant, 10 Granborough Road, Winslow, Buckinghamshire, MK18 3BP

*orresponding Author (steelemi@elanco.com)
}

ISSN: 2396-9776

Published: 2016

in: Vol 1, Issue 3

DOI: http://dx.doi.org/10.18849/ve.v1i3.39

Reviewed by: James Breen (BVSc PhD DCHP MRCVS)

Next Review Date: 20 Jan 2018 


\section{KNOWLEDGE SUMMARY}

\section{Clinical bottom line}

Heat stress appears to generally suppress innate immune function in both dry and lactating dairy cows. Immune effects that are decreased include cytokine production, proliferation of immune cells, migration of lymphocytes to the udder and cell viability. This may lead to an increase in the risk of clinical diseases such as mastitis and metritis.

\section{Question}

In dairy cows experiencing heat stress (in most papers defined as a temperature/humidity index of $>65$ at the lowest threshold (Bernabucci, 2014), vs. cows in environmentally cooled conditions, is innate immune functionality affected?

\section{The evidence}

A previously published review revealed that cows experiencing high temperature humidity indices reduce milk yields beyond that expected of the reduction in dry matter intake (Baumgard, 2013) and therefore do not appear to experience ketosis. It is clear however, that cows experience some discomfort. The innate immune system is the first line of defense against invading pathogens, and any factor which suppresses the efficiency of this protection increases the risk of diseases (Kehrli, 1989).

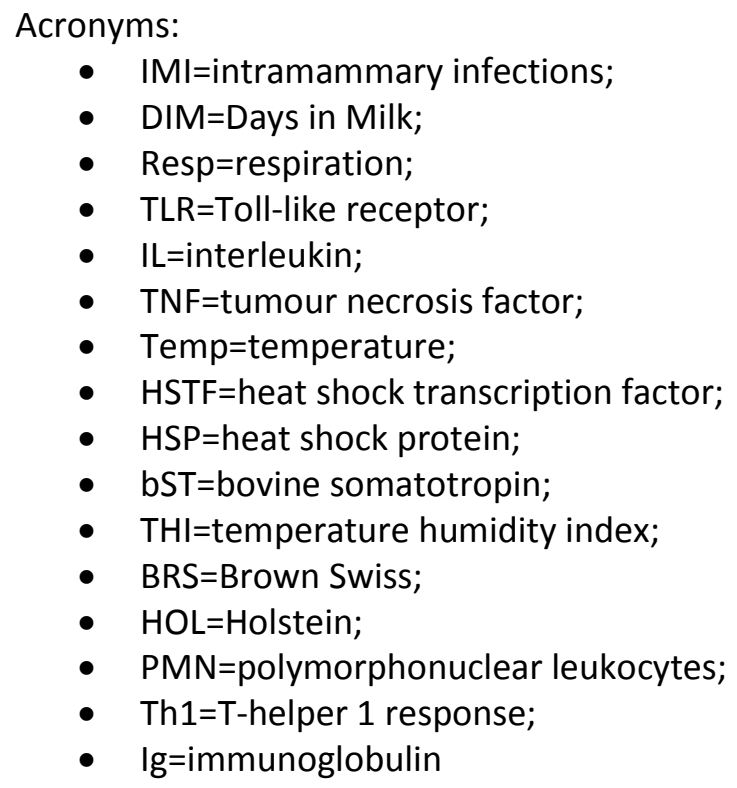




\begin{tabular}{|c|c|}
\hline \multicolumn{2}{|l|}{ Thompson (2014) } \\
\hline Population: & Multiparous dairy cows in the dry period \\
\hline Sample size: & $\begin{array}{l}15 \text { cooled dry cows and } 15 \text { heat stressed cows. } 5 \text { from each group } \\
\text { were induced Streptococcus uberis IMI at 5DIM }\end{array}$ \\
\hline Intervention details: & $\begin{array}{l}\text { THI in non-cooled conditions was 77.9-78.3. Cooling involved fans, } \\
\text { water sprinklers and shade in this group }\end{array}$ \\
\hline Study design: & Cohort Study \\
\hline Outcome studied: & $\begin{array}{l}\text { Rectal temperature, respiratory rate, milk yield and composition, } \\
\text { blood parameters: Immune response genes (TLR2, IL1- } \beta \text {, IL6, IL8, } \\
\text { IL10, and TNF } \alpha \text { ) }\end{array}$ \\
\hline $\begin{array}{l}\text { Main findings: } \\
\text { (relevant to PICO question): }\end{array}$ & $\begin{array}{l}\text { Cooled dry cows had: } \\
\text { - Lower temperature and respiratory rate, } \\
\text { - Higher milk yield (no change in composition) by } 3.8 \mathrm{~L} / \mathrm{d} \\
\text { - Higher neutrophil count after IMI } \\
\text { - Higher IL10 } \\
\text { - Higher TLR2 } \\
\text { - } \text { All other cytokines had no difference }\end{array}$ \\
\hline Limitations: & $\begin{array}{l}\text { - Very low cow numbers } \\
\text { - Measured over 0-36 hours post IMI for cytokines and to } 40 \\
\text { - } 4 \text { All cows into lactation for physiology } \\
\text { - Insufficient power to conclude an effect on milk yield, } \\
\text { however, any numerical effects seen are valid as the } \\
\text { primiparous group were not included }\end{array}$ \\
\hline
\end{tabular}

\begin{tabular}{|c|c|}
\hline \multicolumn{2}{|l|}{ Collier (2008) } \\
\hline Population: & Dairy cows experiencing heat stress $>35^{\circ} \mathrm{C}$ \\
\hline Sample size: & NA \\
\hline Intervention details: & NA \\
\hline Study design: & Review of cohort studies \\
\hline Outcome studied: & NA \\
\hline $\begin{array}{l}\text { Main findings: } \\
\text { (relevant to PICO question): }\end{array}$ & $\begin{array}{l}\text { Gene expression changes to heat above } 35^{\circ} \mathrm{C} \text { include: } \\
\text { - } \text { activation of heat shock transcription factor } 1 \mathrm{HSTF} 1 \\
\text { - increased expression of heat shock proteins (HSP) } \\
\text { - increased glucose and amino acid oxidation and reduced } \\
\text { - fatty acid metabolism } \\
\text { - immune system activation via extracellular secretion of HSP }\end{array}$ \\
\hline Limitations: & NA \\
\hline
\end{tabular}




\begin{tabular}{|r|l|}
\hline \multicolumn{2}{|c|}{ Kamwanja (1994) } \\
\hline Population: & Lymphocytes from 3 breeds of heifers \\
\hline Sample size: & 12 heifers of Angus, Brahman and Senepol \\
\hline Intervention details: & Killing lymphocytes after incubation at $45^{\circ} \mathrm{C}$ for 1 or 12 hours \\
\hline Study design: & Cohort study on lymphocyte populations \\
\hline Outcome studied: & $\begin{array}{l}\text { Viability of lymphocytes and } \mathrm{HSP} \text { production when killed after } 45^{\circ} \mathrm{C} \\
\text { for } 1 \text { hour or } 12 \text { hours }\end{array}$ \\
\hline $\begin{array}{r}\text { Main findings: } \\
\text { (relevant to PICO question): }\end{array}$ & Decrease in viability at $45^{\circ} \mathrm{C}$ in Brahman and Senepol \\
\hline Limitations: & In vitro work with little relevance to in vivo effects \\
\hline
\end{tabular}

\begin{tabular}{|c|c|}
\hline \multicolumn{2}{|l|}{ Elvinger (1992) } \\
\hline Population: & Dairy cows during lactation \\
\hline Sample size: & $\begin{array}{l}34 \text { cows at parity } 1-8 \text { and DIM } 30-209 \text { given either bST or placebo } \\
\text { (16 in control, } 18 \text { in bST treated group). On day } 10 \text { after initialising } \\
\text { placebo or bST cows were placed in cross over heat stress and } \\
\text { normalised environments) }\end{array}$ \\
\hline Intervention details: & Heat stress $\left(35-44^{\circ} \mathrm{C}\right)$ or normalised $\left(26-33^{\circ} \mathrm{C}\right)$ \\
\hline Study design: & Cohort study (cross-over) \\
\hline Outcome studied: & $\begin{array}{l}\text { Temperature, respiratory, cortisol, milk yield, lymphocyte numbers } \\
(C D 4+\text { and } 8+)\end{array}$ \\
\hline $\begin{array}{l}\text { Main findings: } \\
\text { (relevant to PICO question): }\end{array}$ & $\begin{array}{l}\text { - Heat stress increased rectal temperatures, respiration rates, } \\
\text { and plasma cortisol concentrations and decreased milk yield } \\
\text { - No discernible effects on immune function due to bST } \\
\text { - Heat stress reduced lymphocyte migration to udder }\end{array}$ \\
\hline Limitations: & $\begin{array}{l}\text { - Very low cow numbers } \\
\text { - Cows ranged from lactation 1-8 with no specification as to } \\
\text { numbers in each lactation. This may affect yield results } \\
\text { (lactation } 1 \text { cows give less milk than lactation }>1 \text { ). }\end{array}$ \\
\hline
\end{tabular}

\begin{tabular}{|r|l|}
\hline \multicolumn{2}{|c|}{ Elvinger (1991) } \\
\hline Population: & Heat stressed lactating dairy cows \\
\hline Sample size: & NA \\
\hline Intervention details: & Incubated lymphocytes in high or low temperatures to see viability \\
\hline Study design: & Case study \\
\hline Outcome studied: & Viability of leukocytes incubated at $38^{\circ} \mathrm{C}$ and $42^{\circ} \mathrm{C}$ \\
\hline Main findings: & During spring THI was 72 and in the summer it was 79. \\
\hline (relevant to PICO question): & In summer: \\
\hline
\end{tabular}




\begin{tabular}{|l|l|}
\hline & $\begin{array}{l}\text { - DNA synthesis was lower } \\
\text { - Immunolglobulin M secretion was higher }\end{array}$ \\
\hline Limitations: $\begin{array}{l}\text { Plasma cortisol was higher (2ng vs }>4 \mathrm{ng} / \mathrm{ml} \text { before calving, } \\
\text { not after) }\end{array}$ & $\begin{array}{l}\text { The cows weren't grouped } \\
\text { Variation in feed possible and other management factors (stocking } \\
\text { etc.) }\end{array}$ \\
\hline
\end{tabular}

\begin{tabular}{|c|c|}
\hline \multicolumn{2}{|l|}{ Lacetera (2006) } \\
\hline Population: & Comparing leukocytes from BRS and HOL lactating dairy cows \\
\hline Sample size: & $5 \mathrm{BRS}$ and $5 \mathrm{HOL}$ cows \\
\hline Intervention details: & Incubation of $\mathrm{PMNs}$ at $39^{\circ} \mathrm{C}$ and $43^{\circ} \mathrm{C}$ \\
\hline Study design: & Cohort study \\
\hline Outcome studied: & $\begin{array}{l}\text { PMN: } \\
\text { Proliferation } \\
\text { HSP72 synthesis }\end{array}$ \\
\hline $\begin{array}{r}\text { Main findings: } \\
\text { (relevant to PICO question): }\end{array}$ & $\begin{array}{l}\text { - PMNs from BRS breed appeared to have a lower } \\
\text { tolerance to heat. BRS is supposed to be a more heat } \\
\text { tolerant breed. } \\
\text { - Heightened temperature } \\
\text { - } \text { Lowered ROS activity } \\
\text { - Higher HSP72 synthesis in BRS but not HOL } \\
\text { temperatures than BRS }\end{array}$ \\
\hline Limitations: & $\begin{array}{l}\text { - Low numbers of cows, however the study is comparing } \\
\text { cells rather than cows } \\
\text { HSP72 synthesis may not be conclusive as it is unclear } \\
\text { whether or not pre-or post-transcription levels on mRNA } \\
\text { are determined. }\end{array}$ \\
\hline
\end{tabular}

\begin{tabular}{|c|c|}
\hline \multicolumn{2}{|l|}{ Lacetera (2005) } \\
\hline Population: & Transition HOL dairy cows (dry and in early lactation) \\
\hline Sample size: & $\begin{array}{l}34 \text { cows. } 28 \text { calving in spring and } 12 \text { in summer. During spring THI } \\
\text { averaged } 72 \text { and in the summer it averaged } 79 .\end{array}$ \\
\hline Intervention details: & Comparing cows calving in spring and summer \\
\hline Study design: & Cohort study \\
\hline Outcome studied: & Blood (leukocytes) taken weekly, from $-4 w k$ to $+4 w k$ around calving \\
\hline $\begin{array}{l}\text { Main findings: } \\
\text { (relevant to PICO question): }\end{array}$ & $\begin{array}{l}\text { In summer: } \\
\text { - DNA synthesis was lower } \\
\text { - IgM secretion was higher } \\
\text { - Plasma cortisol was higher ( } 2 \mathrm{ng} \text { vs }>4 \mathrm{ng} / \mathrm{ml} \text { before calving, }\end{array}$ \\
\hline
\end{tabular}




\begin{tabular}{|l|ll|}
\hline & not after) \\
\hline Limitations: & - Very low cow numbers \\
& - $\quad$ Many more cows in winter group vs summer group \\
& - Variation in feed possible and other management factors \\
& & $\begin{array}{l}\text { (stocking etc.) from spring to summer. This may have } \\
\text { affected physiological factors }\end{array}$ \\
\hline
\end{tabular}

\begin{tabular}{|c|c|}
\hline \multicolumn{2}{|l|}{ Do Amaral (2010 and 2011) } \\
\hline Population: & $\begin{array}{l}\text { Comparing lymphocyte function in heat stressed and cooled } \\
\text { multiparous lactating cows }\end{array}$ \\
\hline Sample size: & $\begin{array}{l}21 \text { heat stressed and } 16 \text { cooled lactating cows (from } 42 \text { days pre } \\
\text { calving) }\end{array}$ \\
\hline Intervention details: & Cooling system had fans and sprinklers active at greater than $21^{\circ} \mathrm{C}$. \\
\hline Study design: & Cohort study \\
\hline Outcome studied: & $\begin{array}{l}\text { mRNA expression of prolactin receptor PRL-R, Suppressor of cytokine } \\
\text { activity proteins SOCS-1, SOCS-2, SOCS-3, cytokine-inducible SH2- } \\
\text { containing protein, and heat shock protein } 70 \text { typed at Kilodalton A5 } \\
\text { (or HSPA5) }\end{array}$ \\
\hline $\begin{array}{l}\text { Main findings: } \\
\text { (relevant to PICO question): }\end{array}$ & $\begin{array}{l}\text { Heat stress: } \\
\begin{array}{l}\text { - Had greater prolactin (PRL) in plasma } \\
\text { - Had lower lymphocyte proliferation } \\
\text { - Had lower SOCS (suppressors of cytokine function) levels } \\
\text { - Had lower TNFa expression } \\
\text { - Had lower PRL receptor expression }\end{array}\end{array}$ \\
\hline Limitations: & $\begin{array}{l}\text { - } \quad \text { Low cow numbers } \\
\text { - Did not concentrate on many innate, Th1 parameters } \\
\text { - Did not mention the difference in temperature of cooled vs } \\
\text { heat stressed groups }\end{array}$ \\
\hline
\end{tabular}

\begin{tabular}{|c|c|}
\hline \multicolumn{2}{|l|}{ Lacetera (2002) } \\
\hline Population: & Transition dairy cows in spring and summer \\
\hline Sample size: & 20 spring calving cows and 9 summer calving cows \\
\hline Intervention details: & $\begin{array}{l}\text { spring THI } 58 \\
\text { Summer THI } 72\end{array}$ \\
\hline Study design: & Cohort study \\
\hline Outcome studied: & $\begin{array}{ll}\text { - } & \text { Rectal temperature } \\
\text { - } & \text { Respiratory rate } \\
\text { - } & \text { Proliferation of PMNs } \\
\text { - } & \text { Colostrum Ig levels }\end{array}$ \\
\hline $\begin{array}{l}\text { Main findings: } \\
\text { (relevant to PICO question): }\end{array}$ & $\begin{array}{l}\text { Summer vs spring: } \\
\text { - Increased rectal temperature }\end{array}$ \\
\hline
\end{tabular}


- Increased respiratory rate

- No effect on proliferation or colostrum Ig levels

Limitations: May be different management systems at different times, small cow numbers and very moderate $\mathrm{THI}$ for heat

\section{Appraisal, application and reflection}

There are relatively few papers directly addressing the effects of heat stress on immune function specifically, especially those concentrating on non-specific, innate effects that may be significant to the development of subsequent diseases. However, there are some agreements between the above papers that physiological effects are apparent as well as immune suppressive effects in temperature and humidity levels over THI levels at greater than or equal to 72 .

Most papers compare cooled cows to heat stressed cows and either focus on outcomes in vivo or from leukocytes taken from the cows and subsequent functions in vitro.

Cows or leukocytes in cooled conditions appear to have:

- Lower rectal temperatures

- Lower respiratory rates

- Lower cortisol levels in plasma

- Higher milk yield (3.8L/d)

- Higher IL10,2, neutrophil count, Lower TNF $\alpha$, Lower suppressors of cytokine function

- Higher viability of leukocytes

- No effect on Ig levels in colostrum

- Better migration of lymphocytes to udder

- Higher prolactin receptor expression

- Lower prolactin production

- Higher heat shock transcription factor HSTF1 and heat shock protein HSP72 expression (but(B. U. Lacetera N. 2006) states that the function of the latter molecule remains unknown) but posttranscriptive effects are not determined.

\section{Methodology Section}

\begin{tabular}{|c|c|}
\hline $\begin{array}{r}\text { Databases searched and dates } \\
\text { covered: }\end{array}$ & $\begin{array}{l}\text { Used } 3 \text { databases: PubMed, CAB Abstracts (1973-2015) accessed } \\
\text { on the OVID platform) and Google Scholar. PubMed did not achieve } \\
\text { many hits (5) so I tried Google Scholar. PubMed also had too many } \\
\text { results to process when using immun*, so I had to restrict to } \\
\text { (immune OR immunity). } \\
\text { Hit } 16,400 \text { results. Filtered to } 2000-2016 \text {, After the first } 4 \text { pages, } \\
\text { virtually none were relevant to the PICO. }\end{array}$ \\
\hline Search terms: & $\begin{array}{l}\text { ((((cow\$ AND cattle AND bovi*))) AND heat stress) AND ((immune } \\
\text { OR immunity)) - PubMed } \\
\text { does heat stress affect dairy cow immun* - Google Scholar } \\
\text { (cow\$ AND cattle AND bovi* AND heat stress AND (immune OR } \\
\text { immunity)).mp - CAB Abstracts }\end{array}$ \\
\hline Dates searches performed: & $18^{\text {th }}$ March, 2016 \\
\hline
\end{tabular}




\begin{tabular}{|r|l|}
\hline \multicolumn{2}{|l|}{ Exclusion / Inclusion Criteria } \\
\hline Exclusion: & NA \\
\hline Inclusion: & $\begin{array}{l}\text { Relevance to PICO, sufficient evidence level, answers the clinical } \\
\text { question }\end{array}$ \\
\hline
\end{tabular}

\begin{tabular}{|l|c|c|c|}
\hline \multicolumn{1}{|l|}{ Search Outcome } \\
\hline Database & Number of results & Number of duplicates & Total relevant papers \\
\hline NCBI PubMed & 17 & 12 & 5 \\
\hline Google Scholar & 16,400 & 16,394 & 6 \\
\hline CAB Abstracts & 53 & 47 & 6 \\
\hline Total relevant papers when duplicates removed & & 9 \\
\hline
\end{tabular}

\section{CONFLICT OF INTEREST}

The author declares no conflict of interest.

\section{REFERENCES}

1. Baumgard, L.H, and Rhoads, R.P. (2013) Effects of Heat Stress on Postabsorptive Metabolism and Energetics. Annual Reviews in Animal Biosciences, 1 (1), pp. 311-

337. http://dx.doi.org/10.1146/annurev-animal-031412-103644

2. Bernabucci, U. et al. (2014) The Effects of Heat Stress in Italian Holstein Dairy Cattle. Journal of Dairy Science, 97 (1), pp. 471-486. http://dx.doi.org/10.3168/ids.2013-6611

3. Collier, R.J. et al. (2008) Invited Review: Genes Involved in the Bovine Heat Stress Response. Journal of Dairy Science, 91 (2), pp. 445-454. http://dx.doi.org/10.3168/jds.2007-0540

4. Do Amaral, B.C. et al. (2010) Heat Stress Abatement during the Dry Period Influences Prolactin Signaling in Lymphocytes. Domestic animal endocrinology, 38 (1), pp. 38-

45.http://dx.doi.org/10.1016/i.domaniend.2009.07.005

5. Do Amaral B.C. et al. (2011) Heat Stress Abatement during the Dry Period Influences Metabolic Gene Expression and Improves Immune Status in the Transition Period of Dairy Cows. Journal of Dairy 
Science, 94 (1), pp. 86-96. http://dx.doi.org/10.3168/ids.2009-3004

6. Elvinger, F. Hansen, P.J. and Natzke, R.P. (1991) Modulation of Function of Bovine Polymorphonuclear Leukocytes and Lymphocytes by High Temperature in Vitro and in Vivo. American Journal of Veterinary Research, 52 (10), pp. 1692-1798.

7. Elvinger, F. Natzke, R.P, and Hansen, P.J. (1992) Interactions of Heat Stress and Bovine Somatotropin Affecting Physiology and Immunology of Lactating Cows. Journal of Dairy Science, 75 (2), pp. 449462.http://dx.doi.org/10.3168/ids.S0022-0302(92)77781-9

8. Kamwanja, L.A. et al. (1994) Responses of Bovine Lymphocytes to Heat Shock as Modified by Breed and Antioxidant Status. Journal of Animal Science, 72 (2) pp. 438-444.

9. Kehrli, M.E. Nonnecke, B.J. and Roth, J.A. (1989) Alterations in Bovine Neutrophil Function during the Periparturient Period. American Journal of Veterinary Research, 50 (2) , pp. 207-214.

10. Lacetera, N. et al. (2002) Moderate Summer Heat Stress Does Not Modify Immunological Parameters of Holstein Dairy Cows. International Journal of Biometeorology 46, no. 1 (2002): 33-

\section{7.http://dx.doi.org/10.1007/s00484-001-0115-x}

11. Lacetera, N. et al. (2006) Heat Stress Elicits Different Responses in Peripheral Blood Mononuclear Cells from Brown Swiss and Holstein Cows. Journal of Dairy Science, 89 (12), pp. 46064612.http://dx.doi.org/10.3168/jds.S0022-0302(06)72510-3

12. Lacetera, N. et al. (2005) Lymphocyte Functions in Dairy Cows in Hot Environment. International Journal of Biometeorology, 50 (2), pp. 105-110. http://dx.doi.org/10.1007/s00484-005-0273-3

13. Thompson, I.M. (2014) Effect of Cooling during the Dry Period on Immune Response after Streptococcus Uberis Intramammary Infection Challenge of Dairy Cows. Journal of Dairy Science, 97 (12), pp. 7426-7436. http://dx.doi.org/10.3168/ids.2013-7621 


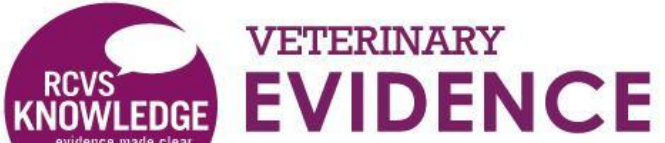 \\ orthe}

\section{Intellectual Property Rights}

Authors of Knowledge Summaries submitted to RCVS Knowledge for publication will retain copyright in their work, but will be required to grant to RCVS Knowledge an exclusive license of the rights of copyright in the materials including but not limited to the right to publish, re-publish, transmit, sell, distribute and otherwise use the materials in all languages and all media throughout the world, and to license or permit others to do so.

Authors will be required to complete a license for publication form, and will in return retain certain rights as detailed on the form.

Veterinary Evidence and EBVM Network are RCVS Knowledge initiatives. For more information please contact us at editor@veterinaryevidence.org.

RCVS Knowledge is the independent charity associated with the Royal College of Veterinary Surgeons (RCVS). Our ambition is to become a global intermediary for evidence based veterinary knowledge by providing access to information that is of immediate value to practicing veterinary professionals and directly contributes to evidence based clinical decision-making.

\section{www.veterinaryevidence.org}

RCVS Knowledge is a registered Charity No. 230886. Registered as a Company limited by guarantee in England and Wales No. 598443.

Registered Office:

Belgravia House

62-64 Horseferry Road

London SW1P 2AF 